\title{
The potential of bacterial isolates for emulsification with a range of hydrocarbons
}

K.S.M. Rahman ${ }^{1 *}$, Thahira J. Rahman ${ }^{1}$, P. Lakshmanaperumalsamy ${ }^{2}$, R. Marchant ${ }^{1}$ and I.M. Banat ${ }^{1}$

1. Biotechnology Research Group, School of Biological and Environmental Science, University of Ulster, Coleraine, County Londonderry, United Kingdom - BT52 1SA.

2. Department of Environmental Sciences, Bharathiar University, Coimbatore - 641046 , Tamilnadu, India.

* Corresponding Author Present address:

Dr Pattanathu K.S.M. Rahman

Chemical and Bioprocess Engineering Group

School of Science and Engineering

Teesside University, Middlesbrough - TS1 3BA

Teesvalley, United Kingdom.

Tel: $\quad+44-1642-384669$

Email: p.rahman@tees.ac.uk

Running title: Emulsification of hydrocarbons by bacteria 


\section{Summary}

A study was undertaken to investigate the distribution of biosurfactant producing, crude oil degrading bacteria in the oil contaminated environment. Our research revealed that hydrocarbon contaminated sites are the potent sources for oil degraders. Among 32 oil degrading bacteria isolated from ten different oil contaminated sites of gasoline and diesel fuel stations, $80 \%$ exhibited biosurfactant production. The quantity and emulsification activity of the biosurfactants varied. Pseudomonas sp. DS10-129 produced maximum of $7.5 \pm 0.4 \mathrm{~g} / 1$ of biosurfactant with corresponding reduction in surface tension from $68 \mathrm{mN} / \mathrm{m}$ to $29.4 \pm 0.7 \mathrm{mN} / \mathrm{m}$ at $84 \mathrm{~h}$ incubation. The isolates Micrococcus sp. GS2-22, Bacillus sp. DS6-86, Corynebacterium sp. GS5-66, Flavobacterium sp. DS5-73, Pseudomonas sp. DS10-129, Pseudomonas sp. DS9-119 and Acinetobacter sp. DS5-74 emulsified xylene, benzene, n-hexane, Bombay High crude oil, kerosene, gasoline, diesel fuel and olive oil. The first five of the above isolates had highest emulsification activity and crude oil degradation ability and they were selected for the preparation of mixed bacterial consortium, which was also an efficient biosurfactant producing oil emulsifying and degrading culture. During this study biosurfactant production and emulsification activity were detected in Moraxella sp., Flavobacterium sp. and mixed bacterial consortium which have not been reported before. 


\section{Introduction}

Biosurfactants are surface-active substances synthesised by living cells. They have the properties of reducing surface tension, stabilising emulsions, promoting foaming and are generally non-toxic and biodegradable. Interest in microbial surfactants has been steadily increasing in recent years due to their diversity, environmentally friendly nature, possibility of large-scale production, selectivity, performance under extreme conditions and potential applications in environmental protection $(1,2)$. Rosenberg and Ron (3) have extensively studied the nature of microbial biosurfactants. The use of chemicals for treatment of a hydrocarbon polluted site may contaminate the environment by their by-products, whereas biological treatment may efficiently destroy pollutants while being biodegradable themselves. Biosurfactants enhance emulsification of hydrocarbons, have the potential to solubilise hydrocarbon contaminants and increase their availability for microbial degradation. Hence, biosurfactant producing microorganisms may play an important role in the accelerated bioremediation of hydrocarbon contaminated sites (3-5). These compounds can also be used in enhanced oil recovery and may be considered for other potential applications in environmental protection $(5,6)$. Other applications include herbicides and pesticides formulations, detergents, health care and cosmetics, pulp and paper, coal, textiles, ceramic processing and food industries, uranium ore-processing and mechanical dewatering of peat $(1,2,7)$.

Several microorganisms are known to synthesize surface-active agents, most of them are bacteria and yeast $(8,9)$. When grown on hydrocarbon substrate as carbon source, these microorganisms synthesize a wide range of chemicals with surface activity such as glycolipid, phospholipid and others $(10,11)$. These chemicals are apparently synthesized to emulsify the hydrocarbon substrate and facilitate its transport into the cells. 
In this paper we described the isolation and identification of several bacterial cultures from oil contaminated sites, capable of growing on hydrocarbon containing media. We also investigated the relationship between biosurfactant production and emulsification activity for various hydrocarbons.

\section{Materials and Methods}

\section{Screening of samples}

Soil samples were collected from gasoline spill (GS) and diesel fuel spill (DS) in gas station soil and wastewater (WW) samples from service stations for the isolation of oil utilizing microorganisms. Enrichment and isolation of oil degrading bacterial cultures were done using mineral salts medium (12) with Bombay High $(\mathrm{BH})$ crude oil as substrate and a serial dilution agar plate technique on nutrient agar medium (Himedia, Mumbai, India).

\section{Characterization of bacteria}

The isolates were grouped to various genera as per Bergey's Manual of Determinative Bacteriology (13). These cultures were characterized depending on their morphology, gram staining, spore staining, motility, oxidase, catalase, oxidation, fermentation, gas production, ammonia formation, nitrate and nitrite reduction, indole, methyl-red, Voges-Proskauer, citrate utilization, utilization of mannitol and urea, hydrolysis of casein, gelatin, starch and lipid (14).

\section{Growth of bacteria on BH crude oil}

The bacterial cultures isolated from oil spill environment were inoculated in mineral salts medium with $1 \% \mathrm{BH}$ crude oil as carbon source. It was kept in the shaker at $200 \mathrm{rpm}$ at $30^{\circ} \mathrm{C}$ for a period of 
seven days. The broth culture was kept undisturbed for an hour to separate the emulsion formed with crude oil at the top of the medium. The culture without oil droplets was used for bacterial growth estimation. The growth was recorded and categorized spectrophotometrically as low growth with optical density (OD) in the range $0.21-0.4$, moderate growth (0.41-0.6 OD), high growth (0.61-0.8 OD) and excellent growth (0.81-1.0 OD) all measured at 620nm (15).

\section{Selection of bacteria for surfactant production}

Among oil degrading isolates 26 isolates showed biosurfactant production and therefore selected for further study (Tab. 1). They belonged to Acinetobacter (1), Alcaligenes (1), Bacillus (4), Corynebacterium (9), Flavobacterium (1), Micrococcus (1), Moraxella (1) and Pseudomonas (8). A consortium consisting of a mixture of five isolates (Micrococcus sp. GS2-22, Bacillus sp. DS686, Corynebacterium sp. GS5-66, Flavobacterium sp. DS5-73 and Pseudomonas sp. DS10-129) was also prepared and used for comparison.

\section{Bacterial growth and biosurfactant production}

A series of $500 \mathrm{ml}$ flasks containing $200 \mathrm{ml}$ of sterile mineral salts medium with $1 \%$ Glucose as substrate were prepared and the $\mathrm{pH}$ was maintained at 7.5. Each of the individual bacterial cultures and the mixed bacterial consortium were inoculated and the flasks were incubated at $30^{\circ} \mathrm{C}$ in a shaker at $200 \mathrm{rpm}$ followed by addition of $1 \%$ glycerol after $24 \mathrm{~h}$. At every $12 \mathrm{~h}$ interval, biomass, biosurfactant production, surface tension and emulsification activity were measured. 


\section{Biomass estimation}

The culture broth was filtered using GF/C filters, The filters were kept at $110^{\circ} \mathrm{C}$ for $24 \mathrm{~h}$. Then they were taken out and weighed. To find the net biomass, the filters were once again burnt in a furnace at $550^{\circ} \mathrm{C}$ and weighed. The net biomass was calculated as the difference between the two.

\section{Biosurfactant extraction}

Surface active compounds were extracted by liquid-liquid extraction (16) from $10 \mathrm{ml}$ of the cell free culture broth previously acidified with $1 \mathrm{~N} \mathrm{HCl}$ to $\mathrm{pH} 2$. Supernatant fluid was mixed with an equal volume of a chloroform: methanol (2:1) mixture. The organic extracts were concentrated by overnight drying in drying chamber at the temperature of $44^{\circ} \mathrm{C}$ and the mass of the biosurfactant was measured.

\section{Surface tension}

Surface tension was measured by drop weight method (17). A vertical fine capillary tube having round tapered nozzle was used. The liquid was drawn and passed slowly to make a fine drop, which hangs by its own weight and then falls down by gravity. The mass of a single drop from cell free culture broth was measured by the average mass of 200 drops for each sample. The following empirical formula was applied to calculate the surface tension in $\mathrm{mN} / \mathrm{m}$.

$$
\mathrm{ST}=\frac{\mathrm{m} \times \mathrm{g}}{3.8 \times \mathrm{r}}
$$

Where,

$$
\begin{array}{lll}
\mathrm{m} & = & \text { mass of single drop of liquid }(\mathrm{mg}) \\
\mathrm{r} & = & \text { radius of the nozzle }(\mathrm{m}) \\
\mathrm{g} & = & \text { gravitational force }
\end{array}
$$




\section{Determination of Emulsification activity}

Emulsification activity (E24) was determined by the addition of the respective hydrocarbon (xylene, benzene, n-hexane, BH crude oil, kerosene, gasoline, diesel fuel and olive oil) to the same volume of cell free culture broth, mixing with a vortex for 2 minutes and leaving to stand for $24 \mathrm{~h}$. The emulsification activity was determined as the percentage of height of emulsified layer $(\mathrm{mm})$ divided by total height of the liquid column (mm) (18).

\section{Results and Discussion}

The enrichment and isolation procedure resulted in 130 pure bacterial cultures able to grow in mineral salts medium (MSM) with BH crude oil as carbon source. Out of 130 isolates, 50.77\%, $24.61 \%, 20.77 \%$ and $3.85 \%$ showed low growth (0.21-0.4 OD), moderate growth (0.41-0.6 OD), high growth (0.61-0.8 OD) and excellent growth (0.81-1.0 OD) at 620nm respectively (Tab. 1). The isolated crude oil degraders belonged to the genera Micrococcus, Corynebacterium, Bacillus, Enterobacteriaceae, Pseudomonas, Alcaligenes, Flavobacterium, Moraxella, Aeromonas, Acinetobacter and Vibrio. The biota reflects the typical heterotrophic bacteria present in soil and native genera seem to be crude oil utilizers. However, the dominant strains belonged to Corynebacterium, Bacillus, Micrococcus and Pseudomonas. The ecological studies of MarquezRocha et al. (19) also identified the above genera among hydrocarbon degrading microorganisms. The addition of hydrocarbons to an ecosystem, as a result of an oil spillage, may selectively increase or decrease the size of microbial population depending upon the chemical composition of the contaminating hydrocarbons and the species of microorganisms present within the microbial community of the particular ecosystem (20). Such an event may enrich primarily for microorganisms capable of utilising the hydrocarbons and secondarily for microorganisms 
capable of utilising metabolites produced by the hydrocarbon-utilising micro-organisms resulting in an increased numbers of hydrocarbon-utilising micro-organisms and associated secondary colonisers. There are numerous reports of such increases in microbial numbers following addition of hydrocarbons to a variety of microbial communities $(12,21)$.

Isolates Micrococcus sp. GS2-22, Corynebacterium sp. GS5-66, Flavobacterium sp. DS5-73, Bacillus sp. DS6-86 and Pseudomonas sp. DS10-129 had the highest growth at $30^{\circ} \mathrm{C}$ in mineral salts medium with $1 \%$ glucose and $1 \%$ glycerol as substrates. Among these genera Pseudomonas sp. DS10-129 produced maximum biosurfactant of $7.5 \pm 0.4 \mathrm{~g} / 1$ at $84 \mathrm{~h}$ with a biomass concentration of $7.1 \pm 0.6 \mathrm{~g} / 1$ in $1 \%$ glucose $+1 \%$ glycerol as substrates and surface tension was reduced from 68 to $29.4 \pm 0.7 \mathrm{mN} / \mathrm{m}$ (Tab. 2). About $0.97-2.7 \mathrm{~g} / 1$ of biosurfactant production by different strains of Pseudomonas aeruginosa using glucose and waste fry oil as carbon source had been reported $(2,22)$. When compared to earlier reports Pseudomonas sp. DS10-129 showed higher quantity of biosurfactant production.

Among the Corynebacterium strains isolated, GS5-66 produced the maximum amount of biosurfactant $(4.1 \pm 0.6 \mathrm{~g} / 1$ at $48 \mathrm{~h})$ in glucose + glycerol and surface tension was reduced to 36.4 $\pm 0.2 \mathrm{mN} / \mathrm{m}$. Similarly, Haferburg et al. (23) reported biosurfactant production by Corynebacterium fascians in media supplemented with yeast extract + hexadecane and kerosene, and observed a reduction in surface tension to 27.5 and $33 \mathrm{mN} / \mathrm{m}$ respectively. Bacillus sp. DS686 produced the maximum quantity of biosurfactant $(2.1 \pm 0.3 \mathrm{~g} / 1$ at $48 \mathrm{~h})$ with the reduction of surface tension to $31.6 \pm 0.9 \mathrm{mN} / \mathrm{m}$. Heba et al. (22) reported the production of lipopeptide biosurfactant by Bacillus subtilis ATCC 6633 with a reduction in surface tension of the medium to $39 \mathrm{mN} / \mathrm{m}$. Similar reduction in surface tension was observed by Jenny et al. (24) by the lipopeptide type of biosurfactant produced by Bacillus licheniformis. Several authors have reported 
similar activity of the biosurfactant produced by Bacillus sp. $(25,26)$. The Acinetobacter sp. DS574 produced $1.9 \pm 0.2 \mathrm{~g} / 1$ of biosurfactant in $96 \mathrm{~h}$ with the reduction in surface tension to $33.7 \pm 0.9$ mN / m. Heba et al. (22) reported lipoprotein type of biosurfactant produced by Acinetobacter calcoaceticus CECT 441 on olive oil and sunflower oil with reduction of surface tension to 42.5 and $38 \mathrm{mN} / \mathrm{m}$ respectively. In the earlier studies, several authors reported about the biosurfactant produced by Acinetobacter sp. (27).

About $2.4 \pm 0.1 \mathrm{~g} / 1$ of biosurfactant was produced by Alcaligenes sp. GS4-49 at $72 \mathrm{~h}$ with reduction in surface tension from $72 \mathrm{mN} / \mathrm{m}$ to $46.2 \pm 0.7 \mathrm{mN} / \mathrm{m}$. Dixon (28) reported that Alcaligenes sp. strain MM-1 produced biosurfactant similar to our findings. The production of 1.3 $\pm 0.2 \mathrm{~g} / 1$ of biosurfactant by Micrococcus sp. GS2-22 that reduced the surface tension to $32.9 \pm$ $0.7 \mathrm{mN} / \mathrm{m}$ was recorded at $72 \mathrm{~h}$ of incubation. Gutnick (29) reported the production of phospholipids and fatty acids/neutral lipid type of surfactant by Micrococcus sp. Other coccal forms such as Streptococcus thermophilus (30) produced biosurfactant, which are applied in fouling control of heat exchanger plates.

Biosurfactant production by Moraxella sp. DS1-13 and Flavobacterium sp. DS5-73 was $1.3 \pm 0.1 \mathrm{~g}$ / 1 and $1.3 \pm 0.7 \mathrm{~g} / 1$ respectively. However we could not find any report on the production of biosurfactant by Moraxella and Flavobacterium in published literature. The mixed bacterial consortium produced about $4.9 \pm 0.8 \mathrm{~g} / 1$ of biosurfactant at $84 \mathrm{~h}$ incubation with biomass of $6.5 \pm$ $0.4 \mathrm{~g} / 1$ and surface tension was reduced to $34.1 \pm 0.3 \mathrm{mN} / \mathrm{m}$. When oil degraders were introduced individually, the amount of surfactant production was more when compared to the production of surfactant by mixed bacterial consortium. This may be due to the competition between the bacteria for nutrient substrate. However, biosurfactant production by mixed bacterial consortium was not reported earlier. 
Petroleum hydrocarbon compounds generally bind to soil particles and are difficult to remove or degrade mainly due to limited availability to micro-organisms (31). Hence for efficient degradation, hydrocarbons should be solubilized prior to microbial degradation (32). Surfactants can emulsify hydrocarbons, thus enhancing their dispersion in water through reduction of surface tension and increased displacement of oily substances from soil particles $(3,33)$. Hydrocarbon contaminants may be nonavailable because of their hydrophobic nature and sorption to soil. Oberbremer et al. (34) showed that both the rate and extent of hydrocarbon degradation in soil slurry were enhanced by biosurfactants. Hence treating soil with biosurfactants will increase the availability of hydrocarbon to the degrading microorganisms, thus stimulating organic biodegradation in the soil.

The emulsification activity is an extensively used method to identify and quantify biosurfactants produced by microbial cultures. Bacillus sp. DS6-86 showed maximum emulsification activity on xylene $(87 \pm 3 \%)$. Banat et al. (35) reported the emulsification activity on xylene during batch fermentation of pet 1006 strain in modified basal salts medium. In the earlier study Pseudomonas sp. MR-3 emulsified xylene to the level of $78.13 \%$ (17). Pseudomonas sp. DS10-129 showed $93 \pm$ $9 \%$ of emulsification activity on benzene and mixed bacterial consortium emulsified olive oil at the maximum of $47 \pm 4 \%$. Heba et al. (22) reported about $61.3 \%$ emulsification activity by the glycolipid biosurfactant produced by Pseudomonas sp. 55T1 on olive oil.

Bacillus sp. DS2-24 showed $87 \pm 6 \%$ of emulsification activity on n-hexane. BH crude oil was emulsified to the maximum of $73 \pm 6 \%$ by Pseudomonas sp. DS10-129. A different strain of the same genera (Pseudomonas sp. MR-3) emulsified 31.70\% (17). Rosenberg et al. (36) also recorded similar findings with Arthrobacter RAG1. Iqbal et al. (18) reported about $70 \%$ of emulsification activity on BH crude oil by Pseudomonas aeruginosa strain S-8. Kerosene was emulsified to $96 \pm 2$ $\%$ by Pseudomonas sp. DS4-55, while other isolates showed lesser activity, which is higher when 
compared to the emulsification activity of Arthrobacter RAG1 (36). In our previous work, about 71.23\% of kerosene was emulsified by Pseudomonas sp. MR-3 (17). Allen et al. (37) reported weaker emulsification activity on kerosene by some microbial isolates from subsurface soil. Johnson et al. (38) isolated Rhodotorula glutunis capable of producing extracellular emulsifying agent on glucose in fed batch fermentation, which emulsified n-hexadecane, xylene, kerosene and gas oil. Muriel et al. (10) observed 55\% emulsification of kerosene by the cladosan biosurfactant produced by Cladosporium resinae. The experimental values obtained in the present investigation were higher when compared to all the earlier reports.

Microbes isolated from gasoline contaminated areas showed emulsification activity when overlaid with gasoline (37). Abu-Ruwaida et al. (39) reported the highest emulsion value (water in oil) of about $78 \%$ using Kuwait motor oil. Moreover, in the present study about $79 \pm 7 \%$ of emulsification activity on gasoline was showed by the surfactants produced by Pseudomonas sp. DS10-129.

Sixty two percent of emulsification activity was observed for diesel fuel by Corynebacterium sp. GS4-48. Willumsen and Karlson (40) found that $67 \%$ of bacterial isolates taken from polyaromatic hydrocarbon (PAH) contaminated soil were able to form detectable emulsion with diesel fuel, whereas the report of Allen et al. (37) also showed weaker emulsification activity by cultures with diesel fuel.

Members of various genera found to be capable of producing surfactants showed emulsification activity on various hydrocarbons. Flavobacterium sp. DS5-73 and Micrococcus sp. GS2-22 produced surfactants which emulsified all the hydrocarbons tested. Allen et al. (37) found that all microbial isolates from subsurface soil contaminated with unleaded gasoline showed emulsification activity when overlaid with gasoline, whereas emulsification activity by microbial cultures overlaid 
with kerosene and diesel fuel were weaker. Willumsen and Karlson (40) found that $67 \%$ of their isolates were able to form detectable emulsions with diesel fuel. One might speculate that this relatively low percentage of emulsifiers among isolates from soil contaminated with PAH as opposed to soil contaminated with aliphatic hydrocarbons might indicate that growth on PAH does not require emulsification to the same extent as growth on aliphatic hydrocarbons. Alternatively, some essential growth factors for emulsification may have been lacking in their study.

\section{Conclusion}

Among the 130 bacterial isolates screened, 32 were efficient oil degraders, $80 \%$ of them were found to produce biosurfactants. Maximum of $7.5 \pm 0.4 \mathrm{~g} / 1$ of surfactant was produced by Pseudomonas sp. DS10-129 and minimum of $0.3 \pm 0.1 \mathrm{~g} / 1$ was produced by Corynebacterium sp. GS5-72. Surfactant production, biomass and emulsification activity reached the maximum at or before $96 \mathrm{~h}$ and was stable thereafter. No single isolate produced surfactant with maximum emulsification activity on all individual hydrocarbons tested. Biosurfactants produced by isolates such as Micrococcus sp. GS2-22, Bacillus sp. DS6-86, Corynebacterium sp. GS5-66, Flavobacterium sp. DS5-73 and Pseudomonas sp. DS10-129, Acinetobacter sp. DS5-74, Pseudomonas sp. GS9-119 and mixed bacterial consortium showed broad spectrum of emulsification activity with all the hydrocarbons tested. Among the biosurfactant producers, all the isolates were able to emulsify xylene and benzene. However, $\mathrm{BH}$ crude oil was emulsified by $88 \%$ of the isolates, n-hexane and diesel fuel by $65 \%$ and kerosene, gasoline and olive oil by $73 \%$ of them. Among the emulsifiers, more than $70 \%$ of the isolates were members of Corynebacterium, Pseudomonas and Bacillus. Our findings showed that the above oil degrading bacteria are efficient biosurfactant producers and hydrocarbon emulsifiers. 


\section{Acknowledgements}

KSM Rahman wishes to thank the Council of Scientific and Industrial Research, New Delhi, India for the award of Senior Research Fellowship. Thanks also to Environment and Heritage Service, DOE for FRDF financial support under the Northern Ireland Single Programme (Ref. WM47/99).

\section{Reference}

[1] BANAT, I.M., MAKKAR, R.S., CAMEOTRA, S.S.: Potential commercial applications of microbial surfactants. Appl. Microbiol. Biotechnol. 53 (2000), 495-508.

[2] RAHMAN, K.S.M., THAHIRA-RAHMAN, J., MCCLEAN, S., MARCHANT, R., BANAT, I.M.: Rhamnolipid biosurfactants production by strains of Pseudomonas aeruginosa using low cost raw materials. Biotechnol Prog. 18 (2002), 1277-1281.

[3] ROSENBERG, E., RON, E.Z.: High and low molecular mass microbial surfactants. Appl. Microbiol. Biotechnol. 52 (1999), 154-162.

[4] DEL 'ARCO, J.P., DE FRANCA, F.P.: Influence of oil contamination levels on hydrocarbon biodegradation in sandy sediments. Environ. Pollut. 110 (2001), 515-519.

[5] RAHMAN, K.S.M., BANAT, I.M., THAHIRA-RAHMAN, J., THAYUMANAVAN, T., LAKSHMANAPERUMALSAMY, P.: Bioremediation of gasoline contaminated soil by a bacterial consortium amended with poultry litter, coir pith and rhamnolipid biosurfactant. Bioresource Technol. 81(2002), 25-32.

[6] SHULGA, A., KARPENKO,E., VILDANOVA-MARTSISHIN, R., TUROVSKY, A., SOLTYS, M.: Biosurfactant enhanced remediation of oil-contaminated environments. Adsorpt. Sci. Technol. 18 (1999), 171-176.

[7] RON, E.Z., ROSENBERG, E.: Natural roles of biosurfactants. Environ. Microbiol. 3 (2001), 229-236.

[8] BANAT, I.M.: Biosurfactants production and possible uses in microbial enhanced oil recovery and oil pollution remediation: a review. Bioresource Technol. 51 (1995), 1-12.

[9] KIM, S.E., LIM E.J., LEE,S.O., LEE ,J.D., LEE, T.H.: Purification and characterization of biosurfactants from Nocardia sp. L-417. Biotechnol. Appl. Biochem. 31 (2000), 249-253.

[10] MURIEL, J.M., BRUQUE, J.M., OLIAS, J.M., SANCHEZ, A.J.: Production of biosurfactants by Cladosporium resinae. Biotechnol. Lett. 18 (1996), 235-240. 
[11] DESAI, J.D., BANAT, I.M.: Microbial production of surfactants and their commercial potential. Microbiol. Mol. Biol. Rev. 61 (1997), 47-64.

[12] RAHMAN, K.S.M., THAHIRA-RAHMAN, J., P.LAKSHMANAPERUMALSAMY., BANAT, I.M., Towards efficient crude oil degradation by Mixed bacterial consortium. Bioresource Technol. 85(2002), 257-261.

[13] HOLT, J.G., KREIG, N.R., SNEATH, P.H.A., STANELY, J.T., WILLIAMS, S.T.: Bergays' Manual of Determinative bacteriology, $9^{\text {th }}$ edition, Williams and Wilkins Publishers, Maryland, (1994).

[14] AARANSON, S.: Experimental Microbial Ecology, Academic press, London (1970).

[15] RAHMAN, K.S.M., THAHIRA-RAHMAN, J., LAKSHMANAPERUMALSAMY, P., BANAT, I.M.: Occurrence of crude oil degrading bacteria in gasoline and diesel station soils. J. Basic Microbiol. 42(2002), 286-293.

[16] ZHANG, Y., MILLER, R.M.: Enhanced octadecane dispersion and biodegradation by a Pseudomonas rhamnolipid surfactant (biosurfactant). Appl. Environ. Microbiol. 58 (1992), 32763282.

[17] RAHMAN, K.S.M., VASUDEVAN, N., LAKSHMANAPERUMALSAMY, P.: Enhancement of biosurfactant production to emulsify different hydrocarbons. J. Environ. Pollut. 6 (1999), 85-93.

[18] IQBAL, S., KHALID, Z.M., MALIK, K.A.: Enhanced biodegradation and emulsification of crude oil and hyperproduction of biosurfactants by a gamma ray-induced mutant of Pseudomonas aeroginosa. Lett. Appl. Microbiol. 21 (1995), 176-179.

[19] MARQUEZ-ROCHA, F.J., HERNANDEZ-RODRI, V., LAMELA, M.T.: Biodegradation of diesel oil in soil by a microbial consortium. Water, Air and Soil Pollut. 128 (2001), 313-320.

[20] ATLAS, R.M.: Microbial degradation of petroleum hydrocarbons, an environmental perspective. Microbiol. Rev. 45 (1981), 180-209.

[21] VENKATESWARAN, K., HOAKI, T., KATO, M., MARUYAMA, T.: Microbial degradation of resins fractionated from Arabian light crude oil. Can. J. Microbiol. 41 (1995), 418-424.

[22] HEBA, E., ESPUNY, M.J., BUSQUETS, M., MANRESA, A.: Screening and production of rhamnolipids by Pseudomonas aeruginosa 47T2 NCIB 40044 from waste frying oils. J. Appl. Microbiol. 88 (2000), 379-387.

[23] HAFERBURG, D., HOMMEL, R., CLAUS, R., KLEBER, H.P.: Extra-cellular microbial lipids as biosurfactants. Adv. Biochem. Eng. Biotechnol. 33 (1986), 53-93.

[24] JENNY, K., KAPPELI, O., FIECHTER, A.: Biosurfactants from Bacillus licheniformis: structural analysis and characterization. Appl. Microbiol. Biotechnol. 36 (1991), 5-13.

[25] BANAT, I.M.: The isolation of a thermophilic biosurfactant producing Bacillus sp. Biotechnol. Lett. 15 (1993), 591-594. 
[26] JACQUES, A.E., PAQUOT, M., FUCHS, R., BUDZIKIEWICZ, H., AKPA T.E.: Influence of culture conditions on lipopeptide production by Basillus subtilis. Appl. Biochem. Biotechnol. 91 (2001), 551-561

[27] ROSENBERG, E., RUBINOVITZ, C., LEGMANN, R., RON, E.Z.: Purification and chemical properties of Acinetobacter calcoaceticus A2 biodispersan. Appl. Environ. Microbiol. 54 (1988), 323-326.

[28] DIXON B.: Oil eaters in nature. Biotechnol. 11 (1993), 525.

[29] GUTNICK, D.: Biosurfactants and the oil industry. The World Biotechnol.. Report 2, (1984), 645-652.

[30] BUSSCHER, H.J., VANDER, M., KUIJL-BOOIJ., VAN DER MEI, H.C.: Biosurfactants from thermophilic dairy Streptococci and their potential role in the fouling control of heat exchanger plates. J. Ind. Microbiol. 16 (1996), 15-21.

[31] PROVIDENTI, M.A., FLEMMING, C.A., LEE, H., TREVORS, J.T.: Effect of addition of rhamnolipid biosurfactants or rhamnolipid producing Pseudomonas aeruginosa on phenanthrene mineralization in soil slurries. FEMS Microbiol. Ecol. 17 (1995), 15-26.

[32] STUCKI, G., ALEXANDER, M.: Role of dissolution rate and solubility in biodegradation of aromatic compounds. Appl. Environ. Microbiol. 53 (1987), 292-297.

[33] ANG, C.C., ABDUL, A.S.: Aqueous surfactant washing of residual oil contamination from sandy soil. Ground Water Monitoring Rev. 11 (1991), 121-127.

[34] OBERBREMER, A., MULLER-HURTIG, R., WAGNER, F.: Effect of the addition of microbial surfactants on hydrocarbon degradation in soil population in a stirred reactor. Appl. Microbiol. Biotechnol. 32 (1990), 485-489.

[35] BANAT, I.M., SAMARAH, N., MURAD, M., HORNE, R., BANERJEE, S.: Biosurfactant production and use in oil tank clean-up. World J. Microbiol. Biotechnol. 7 (1991), 80-84.

[36] ROSENBERG, E., ZUCKERBERG, A., RUBINOVITS, C., GUTNICK, D.L.: Emulsifier of Arthrobacter RAG-1 (i) Isolation and emulsifying properties. Appl. Environ. Microbiol. 37 (1979), 402-413.

[37] ALLEN, P.G., FRANCY, D.S., DUSTON, K.L., THOMAS, J.M., WARD, C.H.: Biosurfactant production and emulsification capacity of subsurface microorganisms. Soil decontamination using biological processes. In: Karlsruhe, E., (Ed.), DECHEMA, Germany, (1992), 29-37.

[38] JOHNSON, V., SINGH, M., SAINI, V.S., ADHIKARI, D.K., SISTA, V., YADAV, N.K.: Bioemulsifier production by an oleaginous yeast Rhodotorula glutinis lip-30. Biotechnol. Lett. 14 (1992), 487-490. 
[39] ABU-RUWAIDA, A.S., BANAT, I.M., HADITIRTO, S., SALEM, A., KADRI, M.: Isolation of biosurfactant - producing bacteria - product characterization and evaluation. Acta Biotechnol. 11 (1991), 315-324.

[40] WILLUMSEN, P.A., KARLSON, U.: Screening of bacteria isolated from PAH contaminated soils for production of biosurfactants and bioemulsifiers. Biodegradation 7 (1997), 415-423. 
Tab. 1 Distribution of bacteria showing different levels of growth on BH crude oil

\begin{tabular}{|c|c|c|c|c|c|}
\hline \multirow{3}{*}{ Genera } & \multicolumn{5}{|c|}{ Growth of bacteria on $\mathrm{BH}$ crude oil } \\
\hline & \multirow[t]{2}{*}{ Total No. } & \multicolumn{4}{|c|}{ Optical Density at $620 \mathrm{~nm}^{*}$} \\
\hline & & $0.21-0.4$ & $0.41-0.6$ & $0.61-0.8$ & $0.81-1.0$ \\
\hline Micrococcus sp. & 17 & 10 & 6 & - & 1 \\
\hline Corynebacterium sp. & 45 & 17 & 17 & 10 & 1 \\
\hline Bacillus sp. & 13 & 8 & 1 & 3 & 1 \\
\hline Enterobacteriaceae sp. & 6 & 4 & 2 & - & - \\
\hline Pseudomonas sp. & 16 & 4 & 2 & 9 & 1 \\
\hline Alcaligenes sp. & 8 & 7 & - & 1 & - \\
\hline Flavobacterium sp. & 9 & 7 & - & 1 & 1 \\
\hline Moraxella sp. & 7 & 5 & 1 & 1 & - \\
\hline Aeromonas sp. & 4 & 2 & 1 & 1 & - \\
\hline Acinetobacter sp. & 2 & 1 & - & 1 & - \\
\hline Vibrio sp. & 3 & 1 & 2 & - & - \\
\hline Total & 130 & 66 & 32 & 27 & 5 \\
\hline Percentage & 100 & 50.77 & 24.61 & 20.77 & 3.85 \\
\hline
\end{tabular}

$*$

$0.21-0.4=$ Low growth $\quad 0.41-0.6=$ Moderate growth

$0.61-0.8=$ High growth $\quad 0.81-1.0=$ Excellent growth 
Tab. 2. Maximum biosurfactant production, growth and surface tension of oil degraders

\begin{tabular}{|c|c|c|c|c|c|c|}
\hline S.No. & Bacteria & $\begin{array}{l}\text { Incubation } \\
\text { (h) }\end{array}$ & $\begin{array}{c}\text { Biosurfactant } \\
(\mathrm{g} / \mathrm{l})\end{array}$ & $\begin{array}{c}\text { Net } \\
\text { biomass } \\
(\mathrm{g} / \mathrm{l})\end{array}$ & $\begin{array}{c}\text { Surface } \\
\text { tension } \\
(\mathrm{mN} / \mathrm{m})^{*}\end{array}$ & $\begin{array}{c}\text { Growth on } 1 \% \\
\text { BH crude oil }\end{array}$ \\
\hline 1 & Acinetobacter sp.DS5-74 & 96 & $1.9^{\mathrm{a}} \pm 0.2^{\mathrm{b}}$ & $4.1 \pm 0.5$ & $33.7 \pm 0.9$ & $\mathrm{H}$ \\
\hline 2 & Alcaligenes sp.GS4-49 & 72 & $2.4 \pm 0.1$ & $1.8 \pm 0.2$ & $46.2 \pm 0.7$ & $\mathrm{H}$ \\
\hline 3 & Bacillus sp.DS1-12 & 48 & $1.8 \pm 0.4$ & $2.3 \pm 0.1$ & $33.1 \pm 0.9$ & $\mathrm{H}$ \\
\hline 4 & Bacillus sp.DS2-24 & 48 & $1.6 \pm 0.2$ & $2.5 \pm 0.3$ & $35.0 \pm 0.2$ & $\mathrm{H}$ \\
\hline 5 & Bacillus sp.DS6-86 & 48 & $2.1 \pm 0.3$ & $2.1 \pm 0.2$ & $31.6 \pm 0.9$ & $\mathrm{E}$ \\
\hline 6 & Bacillus sp.GS3-34 & 48 & $1.8 \pm 0.1$ & $3.7 \pm 0.4$ & $35.2 \pm 0.4$ & $\mathrm{H}$ \\
\hline 7 & Corynebacterium sp.DS3-37 & 120 & $2.6 \pm 0.7$ & $4.3 \pm 0.6$ & $39.7 \pm 0.6$ & $\mathrm{H}$ \\
\hline 8 & Corynebacterium sp.DS3-39 & 96 & $1.9 \pm 0.2$ & $3.9 \pm 0.4$ & $43.1 \pm 0.3$ & $\mathrm{H}$ \\
\hline 9 & Corynebacterium sp.GS5-66 & 48 & $4.1 \pm 0.6$ & $4.2 \pm 0.3$ & $36.4 \pm 0.2$ & $\mathrm{E}$ \\
\hline 10 & Corynebacterium sp.GS4-48 & 24 & $2.1 \pm 0.3$ & $2.5 \pm 0.2$ & $41.2 \pm 0.1$ & $\mathrm{H}$ \\
\hline 11 & Corynebacterium sp.GS4-52 & 96 & $2.4 \pm 0.1$ & $2.8 \pm 0.3$ & $39.3 \pm 0.8$ & $\mathrm{H}$ \\
\hline 12 & Corynebacterium sp.DS5-72 & 96 & $0.3 \pm 0.1$ & $2.9 \pm 0.3$ & $52.5 \pm 0.1$ & $\mathrm{H}$ \\
\hline 13 & Corynebacterium sp.WW1-46 & 24 & $1.4 \pm 0.7$ & $2.0 \pm 0.2$ & $45.4 \pm 0.7$ & $\mathrm{H}$ \\
\hline 14 & Corynebacterium sp.WW4-87 & 48 & $1.7 \pm 0.2$ & $3.5 \pm 0.4$ & $43.7 \pm 0.9$ & $\mathrm{H}$ \\
\hline 15 & Corynebacterium sp.WW4-92 & 72 & $1.2 \pm 0.3$ & $2.9 \pm 0.2$ & $46.8 \pm 0.4$ & $\mathrm{H}$ \\
\hline 16 & Flavobacterium sp.DS5-73 & 72 & $1.3 \pm 0.7$ & $3.3 \pm 0.3$ & $36.1 \pm 0.2$ & $\mathrm{E}$ \\
\hline 17 & Micrococcus sp.GS2-22 & 72 & $1.3 \pm 0.2$ & $1.2 \pm 0.1$ & $32.9 \pm 0.7$ & $\mathrm{E}$ \\
\hline 18 & Moraxella sp.DS1-13 & 72 & $1.3 \pm 0.1$ & $4.8 \pm 0.5$ & $39.5 \pm 0.9$ & $\mathrm{H}$ \\
\hline 19 & Pseudomonas sp.DS10-129 & 84 & $7.5 \pm 0.4$ & $7.1 \pm 0.6$ & $29.4 \pm 0.7$ & $\mathrm{E}$ \\
\hline 20 & Pseudomonas sp.DS1-11 & 48 & $1.7 \pm 0.6$ & $3.2 \pm 0.3$ & $38.2 \pm 0.2$ & $\mathrm{H}$ \\
\hline 21 & Pseudomonas sp.DS1-19 & 48 & $3.1 \pm 0.8$ & $4.5 \pm 0.5$ & $32.5 \pm 0.6$ & $\mathrm{H}$ \\
\hline 22 & Pseudomonas sp.DS3-38 & 48 & $2.1 \pm 0.2$ & $5.7 \pm 0.6$ & $34.2 \pm 0.4$ & $\mathrm{H}$ \\
\hline 23 & Pseudomonas sp.DS4-55 & 96 & $4.7 \pm 0.7$ & $4.2 \pm 0.4$ & $32.2 \pm 0.2$ & $\mathrm{H}$ \\
\hline 24 & Pseudomonas sp.GS4-51 & 72 & $2.6 \pm 0.4$ & $3.0 \pm 0.2$ & $32.7 \pm 0.5$ & $\mathrm{H}$ \\
\hline 25 & Pseudomonas sp.GS8-104 & 72 & $2.4 \pm 0.1$ & $4.4 \pm 0.3$ & $32.4 \pm 0.7$ & $\mathrm{H}$ \\
\hline 26 & Pseudomonas sp.GS9-119 & 96 & $4.3 \pm 0.3$ & $5.3 \pm 0.5$ & $30.6 \pm 0.9$ & $\mathrm{H}$ \\
\hline 27 & Mixed bacterial consortium & 84 & $4.9 \pm 0.8$ & $6.5 \pm 0.4$ & $34.1 \pm 0.3$ & $\mathrm{E}$ \\
\hline
\end{tabular}


Tab. 3. Percentage of emulsification activity of the selected oil degraders on various hydrocarbons

\begin{tabular}{|c|c|c|c|c|c|c|c|c|c|}
\hline S.No & Bacteria & Xylene & Benzene & n-Hexane & BH crude oil & Kerosene & Gasoline & Diesel fuel & Olive oil \\
\hline 1 & Acinetobacter sp.DS5-74 & ${ }^{\mathrm{a}} 26 \pm 7^{\mathrm{b}}$ & $51 \pm 4$ & $48 \pm 4$ & $26 \pm 2$ & $37 \pm 3$ & $6 \pm 1$ & $9 \pm 1$ & $4 \pm 1$ \\
\hline 2 & Alcaligenes sp.GS4-49 & $34 \pm 3$ & $51 \pm 5$ & $27 \pm 2$ & $\mathrm{NE}$ & $15 \pm 1$ & $24 \pm 3$ & $9 \pm 1$ & $8 \pm 1$ \\
\hline 3 & Bacillus sp.DS1-12 & $4 \pm 1$ & $7 \pm 1$ & $\mathrm{NE}$ & $21 \pm 3$ & $\mathrm{NE}$ & $\mathrm{NE}$ & $\mathrm{NE}$ & $13 \pm 2$ \\
\hline 4 & Bacillus sp.DS2-24 & $11 \pm 1$ & $83 \pm 6$ & $87 \pm 6$ & $36 \pm 2$ & $\mathrm{NE}$ & $\mathrm{NE}$ & $\mathrm{NE}$ & $21 \pm 1$ \\
\hline 5 & Bacillus sp.DS6-86 & $87 \pm 3$ & $37 \pm 2$ & $20 \pm 1$ & $62 \pm 5$ & $11 \pm 1$ & $4 \pm 2$ & $58 \pm 5$ & $5 \pm 1$ \\
\hline 6 & Bacillus sp.GS3-34 & $74 \pm 5$ & $80 \pm 6$ & $\mathrm{NE}$ & $29 \pm 4$ & $11 \pm 1$ & $5 \pm 1$ & $4 \pm 1$ & $\mathrm{NE}$ \\
\hline 8 & Corynebacterium sp.DS3-39 & $84 \pm 4$ & $71 \pm 5$ & $\mathrm{NE}$ & $43 \pm 3$ & $\mathrm{NE}$ & $\mathrm{NE}$ & $\mathrm{NE}$ & $8 \pm 1$ \\
\hline 9 & Corynebacterium sp.GS5-66 & $74 \pm 3$ & $61 \pm 4$ & $70 \pm 6$ & $59 \pm 4$ & $54 \pm 3$ & $27 \pm 1$ & $39 \pm 3$ & $16 \pm 3$ \\
\hline 10 & Corynebacterium sp.GS4-48 & $68 \pm 2$ & $64 \pm 6$ & $73 \pm 3$ & $12 \pm 1$ & $73 \pm 4$ & $48 \pm 3$ & $62 \pm 4$ & $\mathrm{NE}$ \\
\hline 11 & Corynebacterium sp.GS4-52 & $9 \pm 1$ & $33 \pm 3$ & $\mathrm{NE}$ & $29 \pm 3$ & $\mathrm{NE}$ & NE & $\mathrm{NE}$ & $4 \pm 1$ \\
\hline 12 & Corynebacterium sp.DS5-72 & $19 \pm 2$ & $19 \pm 1$ & $37 \pm 1$ & $11 \pm 1$ & $29 \pm 2$ & $35 \pm 5$ & $\mathrm{NE}$ & $31 \pm 3$ \\
\hline 13 & Corynebacterium sp.WW1-46 & $48 \pm 4$ & $61 \pm 3$ & $7 \pm 1$ & $56 \pm 4$ & $29 \pm 4$ & $\mathrm{NE}$ & $6 \pm 1$ & $4 \pm 1$ \\
\hline 15 & Corynebacterium sp.WW4-92 & $61 \pm 5$ & $67 \pm 7$ & $7 \pm 2$ & $4 \pm 2$ & $14 \pm 1$ & NE & $7 \pm 1$ & $\mathrm{NE}$ \\
\hline 16 & Flavobacterium sp.DS5-73 & $3 \pm 1$ & $26 \pm 2$ & $42 \pm 6$ & $68 \pm 6$ & $10 \pm 1$ & $8 \pm 1$ & $24 \pm 2$ & $21 \pm 1$ \\
\hline 17 & Micrococcus sp.GS2-22 & $28 \pm 2$ & $34 \pm 2$ & $19 \pm 2$ & $26 \pm 2$ & $46 \pm 3$ & $35 \pm 6$ & $27 \pm 2$ & $30 \pm 3$ \\
\hline 18 & Moraxella sp.DS1-13 & $14 \pm 1$ & $8 \pm 1$ & $\mathrm{NE}$ & $21 \pm 1$ & $19 \pm 1$ & $6 \pm 1$ & $24 \pm 1$ & $12 \pm 1$ \\
\hline 19 & Pseudomonas sp.DS10-129 & $74 \pm 3$ & $93 \pm 9$ & $78 \pm 4$ & $73 \pm 6$ & $89 \pm 3$ & $79 \pm 7$ & $71 \pm 6$ & $27 \pm 3$ \\
\hline 20 & Pseudomonas sp.DS1-11 & $29 \pm 2$ & $30 \pm 2$ & $\mathrm{NE}$ & $48 \pm 4$ & $4 \pm 1$ & $7 \pm 1$ & $9 \pm 1$ & $8 \pm 1$ \\
\hline 21 & Pseudomonas sp.DS1-19 & $71 \pm 4$ & $82 \pm 6$ & $17 \pm 3$ & $\mathrm{NE}$ & $31 \pm 3$ & $43 \pm 4$ & $4 \pm 1$ & $24 \pm 2$ \\
\hline 22 & Pseudomonas sp.DS3-38 & $78 \pm 9$ & $32 \pm 1$ & $18 \pm 1$ & $51 \pm 4$ & $\mathrm{NE}$ & $4 \pm 1$ & $\mathrm{NE}$ & $6 \pm 1$ \\
\hline 23 & Pseudomonas sp.DS4-55 & $75 \pm 4$ & $70 \pm 6$ & $\mathrm{NE}$ & $5 \pm 1$ & $96 \pm 2$ & $27 \pm 3$ & $\mathrm{NE}$ & $\mathrm{NE}$ \\
\hline 24 & Pseudomonas sp.GS4-51 & $9 \pm 1$ & $7 \pm 1$ & $\mathrm{NE}$ & $47 \pm 4$ & $\mathrm{NE}$ & $1 \pm 0$ & $\mathrm{NE}$ & $\mathrm{NE}$ \\
\hline 25 & Pseudomonas sp.GS8-104 & $37 \pm 2$ & $63 \pm 5$ & $76 \pm 3$ & $36 \pm 3$ & $49 \pm 3$ & $14 \pm 1$ & $10 \pm 2$ & $\mathrm{NE}$ \\
\hline 26 & Pseudomonas sp. GS9-119 & $52 \pm 4$ & $63 \pm 4$ & $72 \pm 6$ & $58 \pm 5$ & $84 \pm 7$ & $48 \pm 3$ & $24 \pm 4$ & $26 \pm 2$ \\
\hline 27 & Mixed bacterial consortium & $44 \pm 3$ & $53 \pm 1$ & $66 \pm 8$ & $67 \pm 6$ & $52 \pm 4$ & $31 \pm 2$ & $5 \pm 1$ & $47 \pm 4$ \\
\hline
\end{tabular}

${ }^{\mathrm{a}}=$ Average value,$\quad{ }^{\mathrm{b}}=$ Standard error $\quad \mathrm{NE}=$ No emulsification detected 
